\title{
Korelasi Bobot Badan dengan Ukuran Linear Tubuh Ternak Babi Jantan Peranakan VDL pada Peternakan Rakyat di Kecamatan Kota Kefamenanu, Kabupaten Timor Tengah Utara
}

\author{
Maria M. Kapitan ${ }^{\mathrm{a}}$, Veronika Y. Beyleto ${ }^{\mathrm{b}}$ dan Agustinus A. Dethan ${ }^{\mathrm{c}}$. \\ ${ }^{a}$ Fakultas Pertanian, Universitas Timor, Kefamenanu, TTU - NTT, 85613, Indonesia. \\ ${ }^{b}$ Fakultas Pertanian, Universitas Timor, Kefamenanu, TTU - NTT, 85613, Indonesia \\ ${ }^{c}$ Fakultas Pertanian, Universitas Timor, Kefamenanu, TTU - NTT, 85613, Indonesia.
}

\section{Article Info}

Article history:

Received 10 Januari 2016

Received in revised form 25 Januari 2016

Accepted 17 Maret 2016

Keywords:

Korelasi

Lingkar Dada

Panjang Badan

Tinggi Pundak

VDL

\section{Abstrak}

Penelitian ini bertujuan untuk mengetahui korelasi bobot badan dengan ukuran linear tubuh ternak babi jantan peranakan VDL $\mathrm{d}$ Kecamatan Kota Kefamenanu. Metode yang digunakan adalah survey dengan teknik wawancara dan pengukuran langsung di lapangan untuk mendapatkan data primer, sedangkan data sekunder diambil dari instansi terkait. Penentuan desa dilakukan secara (purposive sampling) dari 3 kelurahan yang berada di satu kecamatan dengan pertimbangan memiliki populasi babi terbanyak. Parameter yang diukur yaitu bobot badan untuk setiap kelompok umur ternak (anak, muda, dewasa) dan ukuran linear tubuh (panjang badan, lingkat dada, tinggi pundak). Hasil penelitian menunjukkan korelasi antara bobot badan dengan panjang badan untuk kelompok umur anak, muda, dewasa adalah, 0,93; 0,97; 0,96. Korelasi antara bobot badan dengan lingkar dada untuk kelompok umur anak, muda, dewasa, adalah 0,$92 ; 0,97$ 0,97. Korelasi antara bobot badan dengan tinggi pundak umtuk kelompok umur anak, muda, dewasa, adalah 0,93; 0,97; 0,96. Korelasi bersifat positif antara bobot badan dengan ukuran linear tubuh ternak babi jantan peranakan VDL dari berbagai kelompok umur di Kecamatan Kota Kefamenanu. (92016 dipublikasikan oleh JAS

\section{Pendahuluan}

Ternak babi merupakan salah satu komoditas yang memiliki potensi besar untuk dikembangkan karena memiliki sifat-sifat yang menguntungkan antara lain laju pertumbuhan yang cepat dan ternak babi juga merupakan ternak monogastrik yang mempunyai sifat makan yang rakus serta memerlukan pakan yang mempunyai protein, energi, mineral, dan vitamin yang tinggi, Salah satu jenis ternak babi yang banyak dijumpai pada peternakan masyarakat adalah babi peranakan VDL, babi ini merupakan jenis babi tipe pedaging yang diketahui memiliki kemampuan produksi yang tinggi, selain itu memilki daya adaptasi yang tinggi pada lahan kering.

Manajemen pakan merupakan salah satu faktor penentu dalam keberhasilan usaha penggemukan. Pakan yang tepat akan berpengaruh terhadap tercapainya produktivitas ternak secara maksimal. Salah satu ukuran produktivitas adalah melalui penilaian terhadap tubuh ternak, hal ini sesuai dengan pendapat Gunawan (1998).

Di Kecamatan kota kefamenanu populasi ternak babi sangat tinggi yaitu 7.116 (BPS, 2014). Tingginya populasi dan produksi ini disebabkan oleh beberapa faktor antara lain, pakan (tata laksana pemberian pakan yang ketersediaan bahan makanan tersebut dalam jumlah yang cukup, berkualitas baik, selalu tersedia dan harganya terjangkau murah), dan faktor pemasaran yang cukup baik. Akan tetapi dengan data populasi saja tidak dapat memberikan gambaran tentang tingkat produksi ternak babi jantan VDL.

Proses pertumbuhan ternak babi, pertumbuhan kerangka diprioritaskan kemudian baru pertumbuhan daging, dan pada akhirnya terjadinya penimbunan lemak. Keeratan antara hubungan bobot badan dengan lingkar dada, lebih bertahan sampai umur yang lebih tua, dibandingkan dengan keeratan hubungan antara bobot badan dengan ukuran-ukuran tubuh lainnya. Secara umum panjang badan dan lingkar dada bertambah sesuai dengan pertambahan bobot badan.

Ukuran panjang badan banyak dipengaruhi oleh pertumbuhan tulang, sedangkan ukuran lingkar dada banyak dipengaruhi oleh keadaan perdagingan dan perlemakan. Jika keadaan tersebut berjalan normal, maka ternak babi dalam keadaan bentuk badan yang kompak. Artinya semakin panjang dan semakin besar badan akan menyebabkan bobot badan meningkat, hal ini dapat diumpamakan sebagai selinder yang volumenya dipengaruhi oleh tinggi (panjang badan) dan diameter (lingkar dada).

Penimbangan adalah cara terbaik dalam menentukan bobot badan ternak. Namun bobot badan ternak dapat diduga dengan mengukur tubuh ternak. Ukuran-ukuran tubuh ternak yang dapat digunakan untuk menduga bobot badan adalah lingkar dada, tinggi pundak, panjang badan, dalam dada, serta tinggi dan lebar kemudi. Akan tetapi yang paling sering digunakan yaitu panjang badan, lingkar dada, dan tinggi pundak. Ukuran linear tubuh ternak didasarkan pada panjang badan, lingkar dada, dan tinggi pundak, yang merupakan indikator dalam penafsiran berat badan, menyeleksi dan menilai kemampuan produksi seekor ternak.

\section{Metode}

Penelitian ini telah dilaksanakan di Kecamatan Kota Kefamenanu, yakni di Kelurahan Tubuhue, Kelurahan Sasi, dan Kelurahan Bansone, sejak awal Januari sampai akhir Februari tahun 2015.

Ternak yang digunakan dalam penelitian ini adalah ternak babi jantan peranakan VDL dari berbagai kelompok umur, sebagai ternak sampel yaitu kelompok I jantan sepasang gigi seri (umur 0,5-1 tahun) anak, kelompok II jantan gigi seri tetap (umur $\geq 1-2$ tahun) muda, dan kelompok III jantan gigi seri tetap (umur $\geq 2-4$ tahun ) dewasa.

Responden yang digunakan dalam penelitian ini adalah peternak yan memiliki minimal 2 ekor babi jantan peranakan VDL dan pengalaman beternak minimal 3 tahun, sehingga terpilih 30 responden. Pengumpulan data dilakukan dengan metode survei dan pengukuran langsung di lapangan.
Variabel yang akan diamati dalam penelitian ini adalah korelasi bobot badan dengan panjang badan, korelasi bobot badan dengan lingkar dada dan korelasi bobot badan dengan tinggi pundak.

Analisis data dilakukan untuk mengetahui derajat hubungan antara variabel bebas (independent) dengan variabel terikat (dependent) menggunakan korelasi Pearson Product Moment (PPM) atau disebut korelasi pearson. Analisis data dilakukan sesuai petunjuk Irianto (2010).

\section{Hasil dan Pembahasan}

Sistem pemeliharaan ternak babi jantan peranakan VDL yang diterapkan adalah sistem pemeliharaan secara intensif atau dikandangkan dengan bangunan sederhana terbuat dari kayu, bambu, yang beratap alang-alang, lantainya adalah tanah, dan sebagiannya menggunakan setengah tembok, beratap seng, alas kandangnya menggunakan semen. Ventilasi/jalan keluar masuknya udara $100 \%$ ada karena dinding kandang umumnya dibuat hanya setengah bangunan. Lokasi kandang di samping rumah atau di belakang rumah, tujuannya adalah untuk memudahkan pengawasan dan penjagaan dari berbagai gangguan dan pencurian. Masing-masing ternak memiliki satu kandang dalam hal ini kandang individu dengan luas $2 \times 2 \mathrm{~m}^{2}$.

Sebanyak $75 \%$ peternak tidak memiliki lahan untuk pakan ternak sedangkan $25 \%$ memilki lahan untuk pakan ternak seperti ubi, hijauan (Lamtoro), batang jagung dan batang pisang. Pakan yang diberikan sehari-hari adalah dedak padi, jagung, ampas tahu, limbah rumah tangga, limbah rumah makan, limbah pasar (sayur-sayur).

Kandang ternak babi biasanya dibersihkan sehari sekali, tetapi ada sebagian peternak yang membersikan dua kali dalam seminggu karena petani peternak mengalami kekurangan air. Pengontrolan terhadap penyakit selalu diperhatikan dan vaksinasi atau tindakan awal pencegahan terhadap penyakit ternak babi selalu dilakukan.

Peternak yang melaporkan ternak babinya yang sakit ke dokter hewan atau petugas untuk diobati ada $57,5 \%$, disuntik dan diobati sendiri oleh petani peternak ada $32,5 \%$ dan dibiarkan saja ada $10 \%$.

\subsection{Korelasi Bobot Badan dengan Panjang Badan}

Hasil penelitian menunjukkan bahwa besarnya nilai korelasi antara bobot badan dengan panjang badan ternak babi jantan peranakan VDL pada berbagai kelompok umur di kecamatan kota kefamenanu sebagai berikut $r=0,93 ; 0,97$ 0,96 . Nilai korelasi yang positif menunjukkan bahwa setiap peningkatan atau pertambahan bobot badan akan diikuti dengan peningkatan panjang badan ternak babi jantan peranakan VDL. Hal ini sesuai dengan pernyataan Budiono dan Coster (2001) bahwa nilai korelasi positif menunjukkan adanya hubungan yang kuat antara dua variabel. Menurut Saleh (1998) dalam hubungan antara variabel $\mathrm{x}$ dan y tinggi rendahnya keeratan hubungan tersebut ditentukan oleh koefisien korelasinya, apabilah mendekati +1 berarti hubungan kedua variabel $\mathrm{x}$ dan $\mathrm{y}$ adalah sangat erat dan positif. Menurut Galeon (1951) menyatakan bahwa, ada korelasi positif yang nyata antara berat hidup dengan lingkar dada, antara berat hidup dengan panjang badan dan antara panjang badan dengan lingkar dada.

\subsection{Korelasi Bobot Badan dengan Lingkar Dada}

Hasil penelitian menunjukkan bahwa besarnya nilai korelasi antara bobot badan dengan lingkar dada ternak babi jantan peranakan VDL pada berbagai kelompok umur adalah $\mathrm{r}=0,92 ; 0,97 ; 0,97$. Hal ini menunjukan bahwa setiap peningkatan atau pertambahan bobot badan akan diikuti dengan peningkatan lingkar dada ternak babi jantan peranakan VDL di kecamatan kota kefamenanu. Hal ini didukung oleh Rice, et al (1975) yang dikutip oleh Laha (1988), bahwa hubungan antara bobot badan dengan lingkar dada pada dasarnya adalah korelasi yang positif. 
3.3 Korelasi Bobot Badan dengan Tinggi Pundak

Hasil penelitian menunjukkan bahwa besarnya nilai korelasi antara bobot badan dengan tinggi pundak ternak babi jantan peranakan VDL pada berbagai kelompok umur di kecamatan kota kefamenanu sebagai berikut : $r=0,93 ; 0,97$; 0,96 . Hal ini menunjukkan bahwa setiap peningkatan atau pertambahan bobot badan akan diikuti dengan peningkatan tinggi pundak ternak babi jantan peranakan VDL pada peternakan rakyat di kecamatan kota kefamenanu. Hal ini sesuai dengan pernyataan Leading (1996) bahwa korelasi disebut positif apabila peningkatan satu sifat diikuti dengan peningkatan pada sifat lain, dan apabila satu sifat meningkat sedangkan sifat lain berkurang maka korelasinya disebut negatif. Sugeng (1987) menyatakan bahwa hubungan antara pertumbuhan pada permukaan tinggi tubuh seperti berat badan, lingkar dada, dan tinggi pundak pada umur pertumbuhan ternak babi adalah positif.

\section{Simpulan}

Korelasi antara bobot badan dengan panjang badan, lingkar dada, dan tinggi pundak berturut-turut untuk kelompok anak adalah 0,$93 ; 0,92 ; 0,93$. Untuk kelompok muda adalah 0,$97 ; 0,97 ; 0,97$ sedangkan untuk kelompok dewasa adalah 0,$96 ; 0,97 ; 0,96$, sehingga dapat dikatakan bahwa setiap perubahan bobot badan akan diikuti oleh perubahan ukuran linear tubuh (Panjang Badan, Lingkar Dada, dan Tinggi Pundak) pada semua kelompok umur ternak babi peranakan VDL.

\section{Pustaka}

BPS TTU. 2014. Timor Tengah Utara Dalam Angka. BPS TTU. Kefamenanu

Budiono dan Coster, W. 2001. Teori dan aplikasi statistika dan probabilitas. PT. Remaja. Bandung.

Gunawan. 1998. Beternak Babi. Angkasa Bandung. Yokyakarta.

Irianto A. 2010. Statistika Konsep, Dasar, Aplikasi, dan Pengembangannya. Kencana Prenada Media Group. Jakarta.

Laha O. 1988. Korelasi Antara Ukuran Linear Tubuh Dengan Berat Badan Pada Kambing Lokal. Skripsi Fapet Undana Kupang.

Leading Change. 1996. Menjadi Pioner Perubahan Sifat Korelasi Pada Pertumbuhan Ternak Babi. PT. Gramedia Pustaka Utama. Jakarta.

Saleh Samsubar. 1998. Statistik Deskriptip. UPP AMP YKPN. Yogyakarta.

Sugeng, Y.B., 1987. Hubungan Antara Permukaan Tubuh Seperti Tinggi Bobot Hidup, Lebar Dada, Lingkar Dada, Pundak, Pada Berbagai Umur Ternak Babi, Penerbit PT. Penebar Swadaya. Jakarta. 